\title{
An Optimal Cropping Plan for Increasing Crop Productivity and Farm Income in a Selected Coastal Area of Bangladesh
}

\author{
F I M Golam Wahed Sarker ${ }^{1 *}$ and W M H Jaim²
}

\begin{abstract}
This study was undertaken in a selected coastal area of Bangladesh to determine the optimal allocation of farm resources among different crops for increasing crop productivity and farm income. Farm survey method was used to collect data in order to develop linear programming representative farm models. The analysis takes into account crop activities, inputs used, farm size and land types. Optimal plans show mis allocation of existing resources and indicate considerable scope for increasing farm productivity and income by reallocation of existing resources. The mis allocation of resources on large farms was greater than that of small farms. The analysis suggests that by reallocating existing resources, large farms could increase farm income and employment more significantly than the small farms. The research supports the view that the government should maintain a policy that favours optimal allocation of farm resources in coastal area and the extension and NGO workers may provide guidelines to farmers for better allocation of existing farm resources and thus increases crop productivity and farm income in coastal area of Bangladesh.
\end{abstract}

\section{INTRODUCTION}

In Bangladesh, the coastal ecosystem is characterized by salinity, water-logging, tidal flooding and shrimp culture etc. Salinity affects about 0.83 million hectares, scattered over 64 upazilas in 13 coastal districts. Salinity restricts economic use of natural resources (land, water, vegetation etc), affecting crop production in the coastal zone (Shah et al., 2004). During the past few decades, adoption of modern agricultural technologies helped to increase crop production 2 to 3 times in most of Bangladesh. But the technological advancement is yet to reach the coastal region of the country and the farmers cultivate mostly locally adapted rice varieties (Bashar et al., 2004). Cropping intensity and production levels are much lower in this region than the other parts of the country (BBS, 2009). Mostly soil salinity, poor drainage and lack of suitable irrigation water are the major constraints to increase crop productivity in this region (Karim et al., 1990).

The situation in coastal areas is more complicated due to the facts like reduction of the scarce land with growing population, environmental degradation, high illiterate population etc. Therefore, for increasing crop productivity and livelihoods of coastal people it is essential to exploit potentials of coastal lands through promotion of alternative, sustainable and judicious management.
One way to improve use of agricultural land is to provide appropriate technology to grow rice and other Rabi crops in the dry season. Rice cultivation in dry season is possible when suitable irrigation water (non-saline) is availed. About $30 \%$ area of the coastal land is suitable for dry season rice cultivation if water is available. Rainfall in the dry season is scanty and river water becomes unsuitable for irrigation after mid February. River water remains non-saline from June to mid February (Mondal et al., 2004). Therefore, rainwater conservation in monsoon and its use in dry season in conjunction with non-saline river water is a promising option for crops production in dry season. In this context, optimum use/judicious management of existing land and water resources through using optimization technique could help in improving productivity and livelihoods of resource-poor coastal farmers. Thus the objectives of the study are: i) to develop representative farm level models for optimal allocation of the available resources of farmers among different crops in coastal area; and ii) to suggest planning guidelines for integrated and sustainable use of farm resources for increasing crop productivity and farm income in coastal area of Bangladesh.

An Optimal Cropping Plan for Increasing 65 


\section{METHODOLOGY}

Location and sampling: The study site is located in Batiaghata upazila of Khulna district in south western coastal region of Bangladesh, which consists of seven unions. To fulfil the objectives with minimum expenditure and time, one union (salinity affected) was chosen purposely. A total of 100 farmers in different categories (small, medium and large) were selected by using stratified random sampling method. Table 1 shows the selections of sample farms.

Table 1. Distribution of sample farmers by farm sizes

\begin{tabular}{|l|c|c|c|c|}
\hline $\begin{array}{l}\text { Location/ } \\
\text { Union }\end{array}$ & $\begin{array}{c}\text { Large farm } \\
(3.01 \text { ha and above })\end{array}$ & $\begin{array}{c}\text { Medium farm } \\
(1.01 \text { ha } 3.00 \mathrm{ha})\end{array}$ & $\begin{array}{c}\text { Small farm } \\
(0.02 \text { ha- }-1.00 \mathrm{ha})\end{array}$ & $\begin{array}{c}\text { All farm } \\
\text { (no. })\end{array}$ \\
\hline Batiaghata Sadar union & 5 & 18 & 77 & 100 \\
\hline
\end{tabular}

Source: Sarker, 2012.

Primary data were collected by carrying out the field survey from March to July 2008. Secondary data of agro-climatic, infrastructure and other information were collected from Bangladesh Meteorological office, Directorate of Agricultural Extension (DAE), Upazila Agriculture Office and other government publications. The survey period covered three agricultural crop seasons (Kharif I, Kharif II, and Rabi) which also covered three rice growing seasons and it was a normal year. For recording the necessary information, a well-structured and pre-tested survey schedule was used for interviewing the farmers directly.
Analytical technique. Linear programm-ing (LP) technique was used to find the profit maximizing combination of activities, subject to constraints imposed by fixed resources (Hazell and Norton, 1986). The assumed objective function in the study is to maximize gross margins for an annual cycle. Gross margins were calculated by deducting the variable production costs (except labour and power tillers) from the gross return. Labour and power tillers hiring for respective periods were treated as separate activities and the cost of these activities have not been included in the gross margins of individual crops.

The objective function was to:

Maximize: $\mathbf{Z}_{0}=\sum_{j} C_{j} X_{j}-\sum_{t=1}^{12} W_{h} L_{t}-\sum_{t=1}^{7} W_{d} P_{t}$

Subject to

(i) $\sum_{\mathrm{j}} \mathrm{l}_{\mathrm{js}} \mathrm{X}_{\mathrm{j}} \leq \mathrm{L}_{\mathrm{s}}$

(Land, $\mathrm{s}=1$ to 5 )

(ii) $\sum_{\mathrm{j}} \mathrm{h}_{\mathrm{jt}} \mathrm{x}_{\mathrm{j}}-\mathrm{L}_{\mathrm{t}} \leq \mathrm{H}_{\mathrm{t}}$

(Labour, $\mathrm{t}=1$ to 12 )

(iii) $\sum_{\mathrm{j}} \mathrm{d}_{\mathrm{jt}} \mathrm{x}_{\mathrm{j}}-\mathrm{P}_{\mathrm{t}} \leq \mathrm{D}_{\mathrm{t}} \quad$ (Power tillers, $\mathrm{t}=1$ to 7 )

(iv) $\sum_{j} w_{j t} x_{j} \leq W_{t}$

(Irrigation water, $\mathrm{t}=1$ to 7 )

(v) $\sum_{\mathrm{j}} \mathrm{c}_{\mathrm{jt}} \mathrm{x}_{\mathrm{j}} \leq \mathrm{C}_{\mathrm{t}}$

(Cash capital, $\mathrm{t}=1$ to 12 )

(vi) $\sum_{\mathrm{j}} \mathrm{f}_{\mathrm{k}} \mathrm{x}_{\mathrm{k}} \geq \mathrm{F}^{(\mathrm{min})}$

(Minimum cereal requirements)

Where,

$Z_{0}=\quad$ total gross margin in taka

$h_{j t}=\quad$ labour requirement for $j^{\text {th }}$ crop activity

$\mathrm{l}_{\mathrm{js}}=\quad$ land coefficient for $\mathrm{j}^{\text {th }}$ crop on $\mathrm{s}^{\text {th }}$ type of

land in hectare

$C_{j}=\quad$ gross margin $(\mathrm{Tk})$ per hectare of the $\mathrm{j}^{\text {th }}$

$x_{j}=\quad j^{\text {th }}$ crop activity for $s^{\text {th }}$ type of land

$X_{j}=\quad$ the area (ha) of the $j^{\text {th }}$ crop activity

$\mathrm{L}_{\mathrm{s}}=\quad$ available $\mathrm{s}^{\text {th }}$ type of land in hectares

$W_{h}=\quad$ wage rate (Tk) per unit of labour

66 Sarker \& Jaim 
Bangladesh Rice J. 18(1\&2): 65-72, 2014

$L_{t}=\quad$ number of hire labour (man-days) in $\mathrm{t}^{\mathrm{th}}$ period

$\mathrm{H}_{\mathrm{t}}=$ labour (man-days) available in $\mathrm{t}^{\text {th }}$ period

$\mathrm{d}_{\mathrm{jt}}=\quad$ power tiller requirement for $\mathrm{j}^{\text {th }}$ crop activity in $\mathrm{t}^{\text {th }}$ period in hours

$\mathrm{x}_{\mathrm{j}}=\quad$ the level of the $\mathrm{j}^{\mathrm{th}}$ crop activity

$W_{d}=$ hiring charge (Tk) per unit of power tillers

$P_{t}=\quad$ power tillers hours hired in $t^{\text {th }}$ period

$\mathrm{D}_{\mathrm{t}}=\quad$ power tiller available in $\mathrm{t}^{\text {th }}$ period

$w_{j t}=\quad$ irrigation water requirement $\left(\mathrm{m}^{3}\right)$ for $\mathrm{j}^{\text {th }}$ crop activity in $\mathrm{t}^{\text {th }}$ period in $\mathrm{m}^{3}$

$W_{t}=$ irrigation water available $\left(\mathrm{m}^{3}\right)$ in $\mathrm{t}^{\text {th }}$ period

$c_{j t}=\quad$ capital requirement in taka for $j^{\text {th }}$ crop activity in $\mathrm{t}^{\text {th }}$ period

$\mathrm{C}_{\mathrm{t}}=$ cash capital available in $\mathrm{t}^{\text {th }}$ period in taka

$\mathrm{f}_{\mathrm{k}}=\quad$ cereal production in $\mathrm{kgs}$ of $\mathrm{k}^{\text {th }}$ crop activity

$\mathrm{X}_{\mathrm{k}}=\quad$ the level of the $\mathrm{k}^{\text {th }}$ cereal crop activity

$F^{(\min )}=$ minimum cereal requirements in $\mathrm{kg}$ for the farm family

The non-negativity restrictions were:

$$
x_{j} \geq 0, L_{t} \geq 0, P_{t} \geq 0, I_{t} \geq 0
$$

Subject to land, labour, power tillers, irrigation water, working capital and minimum cereal requirement constraints.

\section{RESULTS AND DISCUSSION}

\section{Resource utilization}

Land: Optimization and reallocation of available resources using LP model indicated changes in the existing land use pattern (Table 2). The crops BR11 and BR23 were found prime place on the medium Aman land for the small, medium and large farms which accounted for 48, 51 and 52\% of the total cropped areas respectively. The next dominant crops on the medium land were BRRI dhan29, hybrid Boro and other Boro which occupied about 25, 16 and $14 \%$ for small, medium and large farms respectively. The optimal plan with cash capital constraint indicates increased use of high non-rice land for pulses and sesame cultivation. Pulses was the dominant crop on medium high non-rice land, which accounted around $11 \%$ of the total cropped area for large and medium farms. Sesame (Lal til) was dominant crop for small farms which accounted $7 \%$ of total cropped area on medium-high non-rice land. Optimal plans indicates that the area under vegetables may be increased around $1 \%$ over the existing land allocation under all farm situations. In the low rice land situation, the areas for large and medium farms under fish culture were around $2 \%$, which were higher than the existing land allocation. About 77, 80 and $81 \%$ land were under cereal production for large, medium and small farms, respectively. All these changes indicates increases cropping intensity for all (Table 2). Commercial crops like pulses, sesame, vegetables as well as fish were found important for all categories of farms depending on land type. 
Bangladesh Rice J. 18(1\&2): 65-72, 2014

Table 2. Existing and optimal land use (ha) for crop production among farms in Batiaghata sadar area.

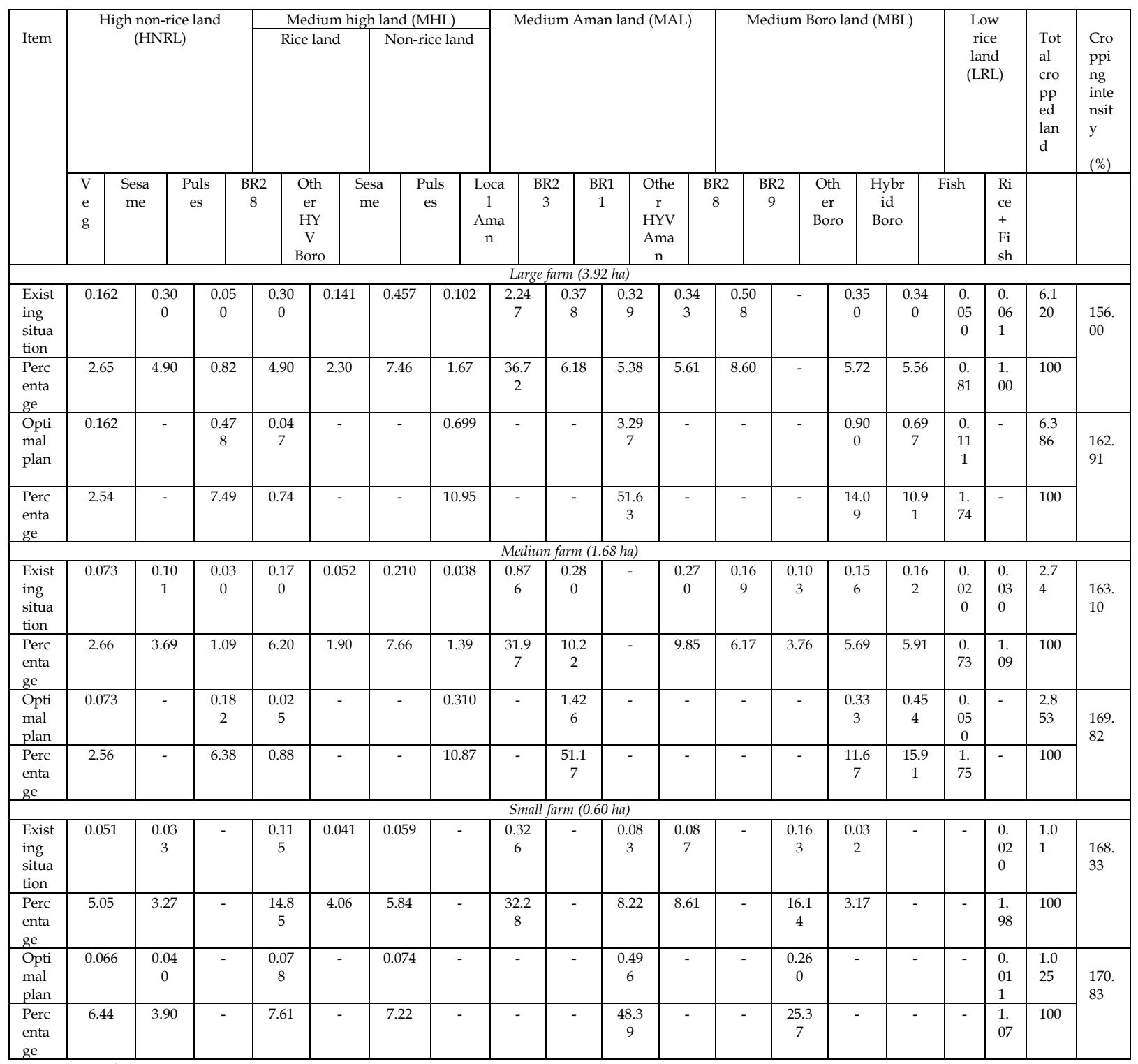

Source: Sarker, 2012.

Labour: Table 3 shows the use of labour under existing and optimal production plans in different farms which revealed that total employment of labour increased by 2, 11 and $18 \%$ for large, medium and small farms respectively compared to the existing plan. This was due to the transfer of more land area under HYV Boro, which requires more labour (Table 2). The optimal plan showed that on the small farms, the availability of family labour was sufficient to meet all farming activities. However, large and medium farms need to hire more labour (181 man-days and 50 man-days respectively) on daily basis to perform farming operations on time. Human labour hiring was observed in January, May, July and November for large farms. January to May were the peak months for HYV Boro, sesame and Rabi crops, which demand more labour for planting, intercultural operations like weeding, irrigating, and post harvest operations. The results of the analysis suggest that increase of annual labour employment on farms was mostly derived from the changes in land use patterns and increased area under HYV Boro area (Table 2). 
Bangladesh Rice J. 18(1\&2): 65-72, 2014

Table 3. Existing and optimal labour use (man-day) among Batiaghata farms

\begin{tabular}{|l|c|c|c|c|c|}
\hline Farm size & $\begin{array}{c}\text { Available } \\
\text { family labour }\end{array}$ & $\begin{array}{c}\text { Existing } \\
\text { situation }\end{array}$ & Optimal plan & \multicolumn{2}{c|}{ Change over existing situation } \\
\cline { 5 - 6 } & 440.80 & 502.25 & 510.03 & Man-day & Percentage \\
\hline Large & 291.45 & 234.07 & 259.36 & 25.78 & 1.55 \\
\hline Medium & 209.35 & 93.78 & 110.23 & 16.45 & 10.80 \\
\hline Small & & &
\end{tabular}

Power tillers: Power tillers were used for land preparation and threshing. Very few farmers had own power tillers and most of the farmers hired it. The optimal plans showed that $272.06,125.13$ and 44.56 hours of power tillers was used by large, medium and small farms respectively to perform the land preparation operations on time, which was 6,7 and $1 \%$ higher than existing plans (Table 4). This was due to the transfer of greater land area under Table 4. Existing and optimal power tiller use (hours) among Batiaghata farms

\begin{tabular}{|l|c|c|c|c|c|}
\hline Farm size & $\begin{array}{c}\text { Available } \\
\text { (family sources) }\end{array}$ & $\begin{array}{c}\text { Existing } \\
\text { situation }\end{array}$ & Optimal plan & \multicolumn{2}{|c|}{ Change over existing situation } \\
\cline { 4 - 6 } & 0 & 257.67 & 272.06 & 14.39 & Hour \\
\hline Large & 0 & 116.74 & 125.13 & 8.39 & 7.19 \\
\hline Medium & 0 & 44.20 & 44.56 & 0.42 & 0.95 \\
\hline
\end{tabular}

Irrigation water: The optimal plans showed $19,051 \mathrm{~m}^{3}, 9,425 \mathrm{~m}^{3}$ and $4,228 \mathrm{~m}^{3}$ of irrigation water used on large, medium and small farms respectively for HYV Boro, vegetables and fish culture, which were almost similar to the existing situations. Among the crops, HYV Boro
HYV aman and Rabi crops production (Table 2). Therefore, during January, July and November higher use of power tiller was observed for land preparation in the optimal plans. For T. Aman, and Boro land preparation, power tillers is most popular tillage implement as it requires shorter land preparation time (turn-around time) and the farmers are cultivating larger areas of these crops. rice requires more water than the other crops. Large amounts of irrigation water would be needed in January to April due to HYV Boro cultivation as shown in both the existing situations and optimum plans (Table 5).

Table 5. Existing and optimal irrigation water use $\left(\mathrm{m}^{3}\right)$ among Batiaghata farms

\begin{tabular}{|l|c|c|c|c|}
\hline Farm size & $\begin{array}{c}\text { Existing situation } \\
\left(\mathrm{m}^{3}\right)\end{array}$ & $\begin{array}{c}\text { Optimal plan } \\
\left(\mathrm{m}^{3}\right)\end{array}$ & \multicolumn{2}{|c|}{ Change over existing situation } \\
\cline { 4 - 5 } & $19,305.54$ & $19,050.58$ & -254.94 & Cubic $\left(\mathrm{m}^{3}\right)$ \\
\hline Large & $9,532.63$ & $9,425.34$ & -107.29 & -1.32 \\
\hline Medium & $4,614.16$ & $4,227.76$ & -386.40 & -8.37 \\
\hline Small & &
\end{tabular}

Cereal crop production: Rice is the major cereal crop and its production among farms was significantly greater than home consumption needs in both existing and optimal plans. Optimal plans showed that about 18,655; 7,993 and 2,161 $\mathrm{kg}$ of cereal were surplus for large, medium and small farms respectively, which were 24, 21 and 12\% higher than the existing situation (Table 6). This was due to increased area under HYV Boro production.

Table 6. Cereal production (kg) under existing and optimal plans in Batiaghata sadar area

Table 6. Cereal production (kg) under existing and optimal plans in Batiaghata sadar area
\begin{tabular}{|l|c|c|c|c|c|c|c|}
\hline \multirow{2}{*}{ Farm size } & $\begin{array}{c}\text { Minimum } \\
\text { cereal } \\
\end{array}$ & \multicolumn{2}{|c|}{ Existing situation } & \multicolumn{2}{c|}{ Optimal plan } & \multicolumn{2}{c|}{$\begin{array}{c}\text { Change over existing } \\
\text { situation }\end{array}$} \\
\cline { 3 - 8 } & required & Production & Surplus & Production & Surplus & Surplus & $\%$ \\
\hline Large & 2,001 & 17,068 & 15,067 & 20,656 & 18,655 & 3,588 & 23.81 \\
\hline Medium & 1,424 & 8,023 & 6,599 & 9,417 & 7,993 & 1,394 & 21.12 \\
\hline Small & 1,180 & 3,110 & 1,931 & 3,341 & 2,161 & 230 & 11.92 \\
\hline
\end{tabular}

Source: Sarker, 2012.

Gross margin/Farm income: In linear programming (LP) it is the gross margin (GM) which is maximizes from the optimum combination of enterprises through efficient use of resources (ie, land, labour, power tillers, and irrigation water and cash capital etc). Table 7 reveals that LP solutions showed gross margin of large farms that could be increased from Tk $1,25,029$ to $1,80,540$ from the existing situation. For medium farms the gross margin could be An Optimal Cropping Plan for Increasing 69 
Bangladesh Rice J. 18(1\&2): 65-72, 2014

increased from Tk 58,523 to 85,508. Again, for small farms it could be increased from Tk 23,724 to 28,795 . The analysis shows that for large, medium and small farms, the gross margin could be increased by 44,46 and $21 \%$ respectively from the existing situation. It shows a misallocation of existing resources on farms and considerable scope for increasing farm income through reallocation of existing resources. The misallocation of resources on large and medium farms was greater than on small farms. The results of the analysis also suggest that by reallocating the existing resources, large and medium farms could increase farm income more significantly than small farms.

Table 7. Existing and optimal annual farm income (Tk) in Batiaghata area

\begin{tabular}{|l|c|c|c|c|}
\hline & & & \multicolumn{2}{|c|}{ Change over existing plan } \\
\cline { 3 - 5 } Farm size & Existing situation & Optimal plan & Taka & Percentage \\
\hline Large & $1,25,029$ & $1,80,540$ & 55,511 & 44.40 \\
\hline Medium & 58,523 & 85,508 & 26,985 & 46.11 \\
\hline Small & 23,724 & 28,795 & 5,071 & 21.37 \\
\hline
\end{tabular}

Source: Sarker, 2012.

\section{Marginal value product of resources}

Table 8 presents the marginal value products (MVP) of land, labour, power tillers, irrigation water and cash capital derived from the 'duals' of the optimal solutions to the respective models. The MVP of limiting resources would also tell how much the farmer could be prepared to pay in order to purchase an extra unit of a resource (eg, the price a farmer would be prepared to pay in order to purchase or rent an additional hectare of land or additional mandays of labour etc). Hence, the opportunity cost (or shadow price) of a limiting resource would be equal to its MVP, while for a slack resource it would be zero.

Table 8. MVP for binding constraints of resources for crop production in Batiaghata area

\begin{tabular}{|c|c|c|c|}
\hline Item & Large farm & Medium farm & Small farm \\
\hline \multicolumn{4}{|c|}{ Land $(T k / h a)$} \\
\hline High non-rice land (HNRL) & 18403.67 & 20964.35 & - \\
\hline Medium high non-rice land (MHNRL) & 18403.67 & 20964.35 & - \\
\hline Medium Aman land (MAL) & 16994.82 & 17052.58 & $18,356.93$ \\
\hline Medium Boro land (MBL) & 7565.00 & 8717.70 & 4252.70 \\
\hline Average & $15,341.92$ & $16,924.75$ & $11,304.82$ \\
\hline \multicolumn{4}{|c|}{ Labour (Tk/man-day) } \\
\hline January & 223.02 & 210.76 & - \\
\hline April & 53.03 & 40.76 & - \\
\hline May & 236.15 & 223.16 & 248.93 \\
\hline July & 249.27 & 235.55 & - \\
\hline November & 249.27 & 235.55 & 262.75 \\
\hline \multicolumn{4}{|c|}{ Power tiller (Tk/hour) } \\
\hline January & 131.19 & 123.96 & 138.29 \\
\hline February & 131.19 & 123.96 & 138.29 \\
\hline May & 131.19 & 123.96 & 138.29 \\
\hline July & 131.19 & 123.96 & 138.29 \\
\hline August & 131.19 & 123.96 & 138.29 \\
\hline November & 131.19 & 123.96 & 138.29 \\
\hline December & 131.19 & 123.96 & 138.29 \\
\hline \multicolumn{4}{|c|}{ Cash capital } \\
\hline MVP & 0.312 & 0.240 & 0.383 \\
\hline
\end{tabular}

Land: The MVP of land varied considerably depending on land type and suitability of crop cultivation. The results presented in Table 8 revealed that MVP of land for small farms was less than large farms. The annual shadow values (Tk/ha) of land were Tk 15,342; 16,925 and 11,305 for large, medium and small farms 70 Sarker \& Jaim respectively, which means that value of the objective function would be increased by this amount if one additional hectare of land of this category was included in the plan. Zero shadow value of land indicates some land category that was fallow. Average shadow value of land per year on large farms was Tk 15,342, which was 
less than the existing land rent (Tk 17,290/ha per year). Again, shadow value of Tk 11,305 for small farms was also considerably less than the existing land rent (Tk 17,290/ha per year) prevailed in the study area in 2008. Similar trend of land shadow value was also found in medium farms.

Labour: Table 8 shows the MVP of human labour for different months. In case of small farms, the MVP of labour for different months in the optimal plan was zero (except May and November). This indicates that the available labour was uniformly surplus to the requirement in the optimal plan on small farms. For large and medium farms different results were observed. The positive MVP of labour was observed in January, May, July and November on large and medium farms, that labour was scarce in these periods. January to May were the months for HYV Boro and Rabi crops cultivation time, which demand more labour for planting/sowing, intercultural operations like weeding, irrigating, and postharvest operations. January and July were the peak labour demand months due to HYV Boro and T. Aman transplanting respectively. May and November were the peak labour demand months due to HYV Boro and and T. Aman harvesting respectively. The rationale for varying the MVP of labour was related to the land reallocation to different crops, and consequential readjustment in the land-labour ratio in the crop area under the optimal plans. Zero shadow prices of labour in the small farms models indicated the presence of surplus labour compared to land available for cultivation. This is a real situation in rural Bangladesh.

Power tillers: In the study area all types of farms hired power tillers to perform land preparation operations on time. The positive MVP of power tillers throughout the period indicated that irrespective of farm size, all farms used power tillers. The MVPs of power tillers were Tk 131.19, Tk 123.96 and Tk 138.29 on large, medium and small farms respectively (Table 8), which was higher than the prevailing market rates of $\mathrm{Tk} 100$. This implies that the large, medium and small farmers would ready to pay Tk 131.19, Tk 123.96 and Tk 138.29 respectively for extra hour of power tillers in the situations modeled.

Cash capital: It is evident from the Table 8 that the MVP of cash capital was Tk 0.312, Tk 0.240 and Tk 0.383 for large, medium and small farms respectively. So there exists an urgent need for providing credit facilities for introducing modern seed-fertilizer-irrigation based technology as well as for optimal use of available resources. The MVP arising for a large farm was higher than for a small farm. This indicates that in case of small farm, the capital investment increases at a higher rate of interest. For achieving economic efficiency, capital should be invested to the point where the MVP equals to the interest or borrowing rate.

\section{CONCLUSIONS AND RECOMMENDATIONS}

The study provides farm resource optimization and cropping plans for farmers in a selected coastal area of Bangladesh. The optimal plans increased the cropped areas and thus increased the cropping intensities on farms. Cereal based cropping patterns maintained dominance in both existing and optimal plans. The plans revealed considerable scope for transfer of land from low valued crops to high valued cash crops. The MVP of land varied considerably according to land type.

Model results indicate that large and medium farmers faced scarcity of family labour and thus, hired seasonal labour. But availability of family on small farms was surplus to crop demand. Farmers hired power tillers to perform land preparation on time. The MVP of power tillers was higher than the prevailing market rates.

Analysis by farm size shows that small farmers had a poor resource (land and capital) base but surplus family labour in relation to their land. Therefore, necessary steps should be taken to create both farm and non-farm employment opportunities through providing credit facilities for them.

Regarding cash capital, the plans indicate that MVPs of cash capital were Tk 0.312, 0.240 and 0.383 for large, medium and small farms respectively, which imply that there is a need to provide credit facilities to introduce high valued cash crops as well as for optimal use of resources.

Optimal plans increased farm income by 44 , 46 and $21 \%$ on large, medium and small farms respectively. It clearly shows a misallocation of existing resources on farms and considerable scope for increasing farm income through reallocation of existing resources. In this regard, extension agents as well as NGOs may provide guidelines to farmers for better allocation of existing farm resources. 


\section{REFERENCES}

Bashar, M K, M Khalequzzaman, M S Ahmed and E S M H Rashid. 2004. Utilization of rice diversity through participatory variety selection in southwest Bangladesh. In: Proceedings of the Workshop on Coastal Water Management and Uptake Technologies. Poverty Elimination Through Rice Research Assistance (PETRRA), International Rice Research Institute (IRRI). pp 74-83.

BBS (Bangladesh Bureau of Statistics). 2009. Statistical Year Book of Bangladesh. Ministry of Planning, Government of the People's Republic of Bangladesh.

Hazell, P B and R D Norton. 1986. Mathematical Programming for Economic Analysis in Agriculture. New York and London.

Karim, Z, S G Hussain and M Ahmed. 1990. Salinity problems and crop intensification in the coastal regions of Bangladesh. Soil publication no. 33. Soil and Irrigation Division, Bangladesh Agricultural Research Council (BARC), Dhaka, Bangladesh. pp. 20
Mondal, M K, S P Ritu, M H K Choudhury, A N M Chasi, P K Majumder, M Islam and S K Adhikary. 2004. Socioenvironmental impact of the innovative water management for crop production: The farmers' perspective. In: Proceedings of the Workshop on Coastal Water Management and Uptake Technologies. Bangladesh Rice Research Institute (BRRI), Bangladesh. pp. 38-47

Sarker, F I M G W. 2012. Modeling judicious management of water resources: A new dimension for increasing crop productivity in coastal area of Bangladesh. Unpublished PhD Thesis. Department of Agricultural Economics, Bangladesh Agricultural University (BAU), Mymensingh.

Shah, A L, M S Raman and M A Rashid. 2004. Effect of integrated use of organic and inorganic fertilizer on rice yield in saline soils. In: Proceedings of the Workshop on Integrated Nutrient Management and Water Resources Utilization for Crop Production in the Coastal Saline Zone of Bangladesh. Bangladesh Rice Research Institute (BRRI), Bangladesh. pp. 1-5. 